\title{
Fluorination Assisted Electrothermal Vaporization-Inductively Coupled Plasma Atomic Emission Spectrometry for a Direct Determination of Chromium in Biological Materials
}

\author{
Bin Hu', Zucheng Jiang, Yun'e ZeNG and Hai ZHU \\ Department of Chemistry, Wuhan University, Wuhan 430072, the People's Republic of China
}

\begin{abstract}
Polytetrafluoroethylene (PTFE) was used as a fluorinating agent in order to facilitate a direct analysis of Cr in biological materials by electrothermal vaporization-inductively coupled plasma atomic emission spectrometry. The electrothermal vaporization parameters and the PTFE amount were optimized experimentally. The effects of different matrices on the emission signal of $\mathrm{Cr}$ were investigated in detail. Under the optimal conditions, the detection limit of $\mathrm{Cr}$ is $1.4 \mathrm{ng} \mathrm{m}^{-1}$ and RSD $3.8 \%$ at $0.03 \mu \mathrm{g} \mathrm{ml}^{-1}$. The proposed method has advantages of sensitivity, simplicity, rapidity and no-chemical pretreatment, and has been applied to a direct determination of trace $\mathrm{Cr}$ in serum.
\end{abstract}

Keywords Electrothermal vaporization, inductively coupled plasma atomic emission spectrometry, fluorinating, polytetrafluoroethylene, serum, chromium

Inductively coupled plasma (ICP), as an ideal vaporization/atomization/excitation/ionization source has been widely used for trace and ultratrace element analysis in various materials. In recent years, many spectroanalysts began to study all kinds of sample introduction techniques, such as various nebulizers for solution ${ }^{1,2}$, spark/arc sampling introduction ${ }^{3,4}$, direct sample insertion ${ }^{5,6}$, slurry sample introduction ${ }^{7,8}$ and electrothermal vaporization (ETV). ${ }^{9,10}$ In the field associated with the sample introduction method mentioned above, ETV became of great interest for spectroanalysts, owing to several advantages: small sample volume required, high conversion efficiency and adaptability to both atomic absorption spectrometry (AAS) and atomic emission spectrometry (AES) techniques.

Graphite furnaces have mostly been applied as atomizers/vaporizers. At high temperature, however, the graphite is prone to reacting with such elements as $\mathrm{Ti}$, $\mathrm{Zr}, \mathrm{V}, \mathrm{Cr}, \mathrm{Mo}, \mathrm{W}, \mathrm{Nb}, \mathrm{Ta}, \mathrm{Hf}$ and rare earths to form refractory carbides, which leads to decreasing, and even completely eliminating, the analyte signals. Improved methods have been reported, including the addition of releasing agents which convert the analytes into volatile substances such as halides, or graphite tubes coated with a layer of compacted metal carbides to prohibit carbon from reacting with analyte elements. In a previous study ${ }^{11}$ we investigated fluorinating reactions of $\mathrm{Zr}$ taking place in the graphite tube by ETV-ICP-AES, where polytetrafluoroethylene (PTFE) was used as the fluorinating agent. The detection limit was of the order of pg.

\footnotetext{
$\dagger$ To whom correspondence should be addressed.
}

In this work, PTFE was used as the fluorinating agent in a direct ETV-ICP-AES determination of trace $\mathrm{Cr}$ in serum and other biological samples without chemical pretreatments. The optimal ETV conditions and the concentration of PTFE were estimated experimentally. The influence of different matrices on the emission of $\mathbf{C r}$ was also investigated.

\section{Experimental}

\section{Instrumental and main operating parameters}

An ICP spectrometric system (Beijing, China) with a maximum power of $2 \mathrm{~kW}$, tuned at $27 \pm 3 \mathrm{MHz}$, was used with a conventional plasma torch. The instrumental conditions and spectral line wavelength are listed in Table 1. A WF-1 type power supply with a matching

Table 1 Operating conditions

\begin{tabular}{ll}
\hline Wavelength & $267.716 \mathrm{~nm}$ \\
Incident power & $1.0 \mathrm{~kW}$ \\
Carrier gas (Ar) flow rate & $0.51 \mathrm{~min}^{-1}$ \\
Coolant gas (Ar) flow rate & $161 \mathrm{~min}^{-1}$ \\
Auxiliary gas (Ar) flow rate & $0.81 \mathrm{~min}^{-1}$ \\
Observation height above & $12 \mathrm{~mm}$ \\
$\quad$ the load coil & $25 \mu \mathrm{m}$ \\
Entrance slit width & $25 \mu \mathrm{m}$ \\
Exit slit width & $100^{\circ} \mathrm{C}$, ramp. $5 \mathrm{~s}$, holds $5 \mathrm{~s}$ \\
Drying temperature & $500^{\circ} \mathrm{C}$, ramp. $20 \mathrm{~s}$, holds $10 \mathrm{~s}$ \\
Charring temperature & $2560^{\circ} \mathrm{C}, 3 \mathrm{~s}$ \\
Vaporization temperature & $10 \mu 1$ \\
Sample volume & \\
\hline
\end{tabular}


graphite furnace (Beijing, China) was used for analyte vaporization. The plasma radiation was focused as a 1:1 image on the entrance slit of a monochromator WDG 500-1A (Beijing, China) having a reciprocal linear dispersion of $1.6 \mathrm{~nm} \mathrm{~mm}^{-1}$. The emission was detected by a R456-type photomultiplier tube fitted with a laboratory-made direct current amplifier. The resulting signal was recorded by an $X-Y$ strip chart recorder (Shanghai, China).

\section{Standard solution and reagents}

A stock standard solution with a concentration of $1 \mathrm{mgCr} \mathrm{ml}^{-1}$ was prepared by dissolving $\mathrm{K}_{2} \mathrm{Cr}_{2} \mathrm{O}_{7}$ in twice-distilled water. Both the Triton X-100 and $\mathrm{K}_{2}$ $\mathrm{Cr}_{2} \mathrm{O}_{7}$ used were of analytical grade. $\mathrm{HNO}_{3}$ and $\mathrm{HClO}_{4}$ were of suprapure grade (Shanghai, China). A $60(\mathrm{w} / \mathrm{v})$ $\%$ PTFE emulsion (viscosity $\eta=(7-15) \times 10^{-3} \mathrm{~kg} \mathrm{~m}^{-1} \mathrm{~s}^{-1}$ $\left(25^{\circ} \mathrm{C}\right)$ ) was offered by Institute of Shanghai Organic Chemistry.

\section{Sample preparation}

The human serum sample was stored into a polyethylene bottle until use. A solution of Triton X-100 $(0.1(\mathrm{w} / \mathrm{v}) \%)$ in $0.1(\mathrm{v} / \mathrm{v}) \%$ nitric acid was prepared using deionized and twice-distilled water. Serum sample solutions were diluted with this solution at ratio of $1: 1$. The resulting solutions contained $0,20,40,80$ and $100 \mathrm{ngCr} \mathrm{ml}^{-1}$ in the presence of PTFE, respectively.

An artificial matrix was prepared by dissolving an appropriate amount of $\mathrm{NaCl}, \mathrm{KCl}, \mathrm{CaCO}_{3}$ and $\mathrm{MgCl}_{2}$ in diluted hydrochloric solutions. The final concentrations of $\mathrm{Na}, \mathrm{K}, \mathrm{Ca}, \mathrm{Mg}$ were $3300,1000,400,100 \mu \mathrm{g}$ $\mathrm{ml}^{-1}$, respectively.

\section{Procedure}

After ICP stablizing, $10 \mu$ l of the sample solution containing PTFE was injected into the graphite furnace by a microsyringe. Under the selected conditions the emission intensity of $\mathrm{Cr}$ was measured at $267.716 \mathrm{~nm}$. A calibration curve was constructed with the peak heights.

\section{Results and Discussion}

\section{Optimization of ICP discharge parameters}

The influence of the flow rate of the carrier gas on the ratio of the line intensity to the background $(S / B)$ is shown in Fig. 1. It was found that the highest $S / B$ ratio was obtained at a flow rate of $0.51 \mathrm{~min}^{-1}$. Figure 2 illustrates the dependence of $S / B$ for $\mathrm{Cr}$ on the observation height. It is obvious that the maximum $S /$ $B$ ratio is obtained at a height of $12 \mathrm{~mm}$.

\section{Concentration of PTFE}

Whether the fluorinating reaction is completed or not directly affects the vaporization behavior of the analytes. The concentration of the fluorinating agent used is the primary factor influencing the reaction. Figure $3 \mathrm{dem}$ -

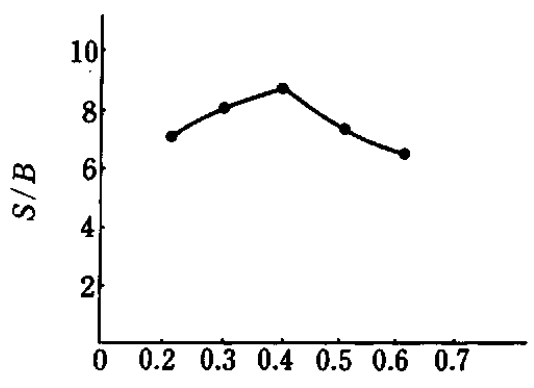

Carrier gas flow rate/ $1 \mathrm{~min}^{-1}$

Fig. 1 Relation between the carrier gas flow rate and the $S / B$ ratio.

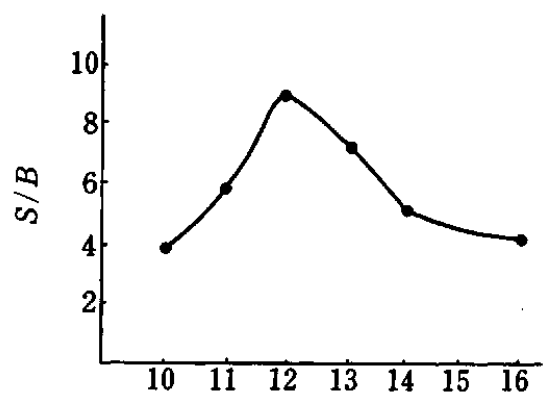

Height above the loading coil $/ \mathrm{mm}$

Fig. 2 Dependence of the $S / B$ ratio on the observation height.

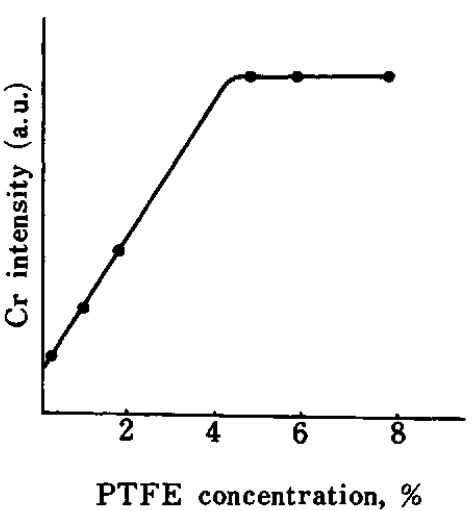

Fig. 3 Dependence of the $\mathrm{Cr}$ emission intensity on the concentration of PTFE.

onstrates the $\mathrm{Cr}$ emission intensity dependence on the concentration of PTFE. The $\mathrm{Cr}$ emission intensity reaches a platform beyond a PTFE concentration of ca. $5 \%$. At higher PTFE concentration than $7 \%$, the ICP discharge became unstable because of vigorous decomposition of PTFE. Therefore, a PTFE concentration of $6 \%$ was used throughout the experiments. 


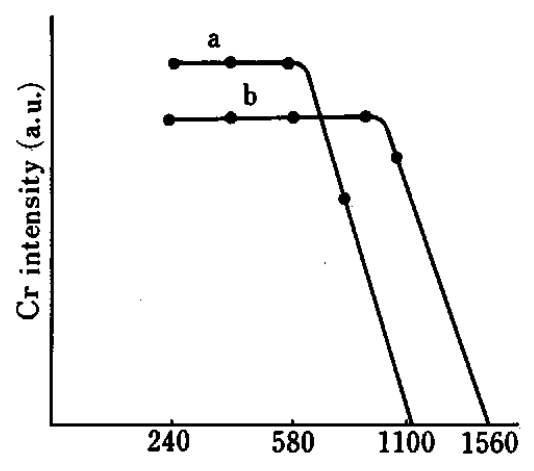

Charring temperature $/{ }^{\circ} \mathrm{C}$

Fig. 4 Dependence of the $\mathrm{Cr}$ emission on the charring temperature. (a) with PTFE and (b) without PTFE.

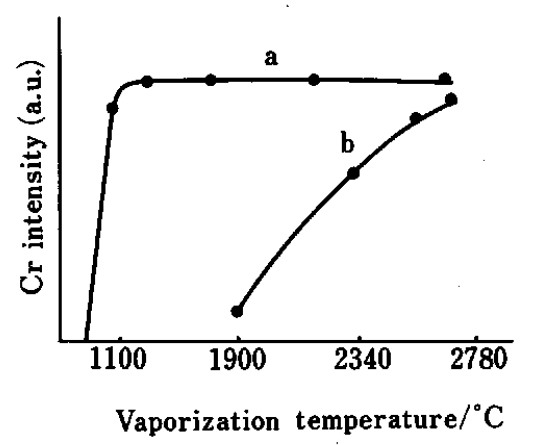

Fig. 5 Dependence of the $\mathrm{Cr}$ emıssion intensity on the vaporization temperature (a) with PTFE and (b) without PTFE.

\section{Optimization in temperature programming}

In order to completely decompose organic matter in biological samples without any loss of the analyte element, it is important to determine the charring temperature adequately. Figure 4 shows the dependence of the $\mathrm{Cr}$ emission intensity on the charring temperature. With the addition of PTFE, a loss of Cr occurs notably at temperature higher than $c a .600^{\circ} \mathrm{C}$, whereas without PTFE, the loss begins at $c a .1100^{\circ} \mathrm{C}$. This indicates that in the presence of PTFE the vaporization of $\mathrm{Cr}$ takes place in the form of volatile fluoride. The maximum charring temperature that can be used without $\mathrm{Cr}$ loss was determined to be $500^{\circ} \mathrm{C}$. Figure 5 shows the $\mathrm{Cr}$ emission intensity dependence on the preset nominal atomization temperature, actually, vaporization temperature in this work. It should be noted that the presence of PTFE greatly influences the vaporization behavior of $\mathrm{Cr}$ and that the vaporization reaches the platform at $1400^{\circ} \mathrm{C}$. On the other hand, no platform is reached in the absence of PTFE. A higher temperature of $2560^{\circ} \mathrm{C}$ is adopted as the vaporization temperature, which would be suitable to multielement determination in extended investigations, though complete vaporization is attainable at much lower temperature.
Table 2 Analytical results for $\mathrm{Cr}$ determination by the fluorinating ETV-ICP-AES

\begin{tabular}{lcc}
\hline \multicolumn{1}{c}{ Sample } & \multicolumn{1}{c}{ Cr found } & \multicolumn{1}{c}{ Ref. value } \\
\hline Human serum $^{\mathrm{a}}$ & $\mathbf{9 . 0 \pm 0 . 8 \mathrm { ng } \mathrm { ml } ^ { - 1 }}$ & $0.2-10 \mathrm{ng} \mathrm{m}^{-1 \mathrm{~b}}$ \\
$\begin{array}{c}\text { NIST 1577 } \\
\text { Bovine Liver }\end{array}$ & $\mathbf{0 . 0 9 5} \pm 0.010 \mu \mathrm{g} \mathrm{g}^{-1}$ & $\mathbf{0 . 0 8 8} \pm 0.012 \mu \mathrm{g} \mathrm{g}^{-1}$ \\
\hline
\end{tabular}

a. Supplied by Guangzhou Military Area Rear-Service General Hospital.

b. Ref. 12.

c. Bovine Liver sample was treated by using the procedure described by Satzger et al. ${ }^{13}$

\section{Matrix effect on fluorinating vaporization}

The influence of single coexisting elements on the fluorinating vaporization was investigated. It was found that the presence of $\mathrm{Na}, \mathrm{K}, \mathrm{Ca}, \mathrm{Mg}$ of up to $5 \mathrm{mg} \mathrm{ml}^{-1}$ caused no significant interference with the fluorinating vaporization of $\mathrm{Cr}$. The effect of a mixed matrix, the composition of which was similar to the serum sample, on the fluorinating vaporization of $\mathrm{Cr}$ was explored. The result showed no influence of the artificial matrix on the vaporization of $\mathrm{Cr}$. To study the interference of the organic matrix with the $\mathrm{Cr}$ determination, the calibration curves for the aqueous solution and the serum sample (standard addition) were compared over a concentration range of $0-100 \mathrm{ng} \mathrm{ml}^{-1}$. The slopes of the calibration curves were almost the same, suggesting that the organic matrix in the serum sample does not interfere with the determination of $\mathrm{Cr}$.

\section{Precision and detection limit}

The RSD at a concentration of $0.03 \mu \mathrm{g} \mathrm{ml}^{-1}$ was $3.8 \%$ $(n=7)$. The detection limit, calculated as three-times the standard deviation at $0.03 \mu \mathrm{g} \mathrm{ml}^{-1}$ was $1.4 \mathrm{ng} \mathrm{ml}^{-1}$. The linear dynamic range of the calibration curves was over three orders of magnitude. This method was applied to a practical analysis of the NIST (National Institute of Standard and Technology, USA) Bovine Liver SRM 1577 and the serum sample. The analytical results are given in Table 2. Fairly good agreement was obtained between the determined and the certificate values for the NIST sample.

\section{References}

1. B. R. Bear and V. A. Fassel, Spectrochim. Acta, 41B, 1089 (1986).

2. J. A. Koropchak and H. Aryamanya-Mugisha, J. Anal. At. Spectrom., 4, 291 (1989).

3. L. J. Prell, S. R. Koirtyohana, Appl. Spectrosc., 42, 1221 (1988).

4. Z. C. Jiang and V. A. Fassel, Gaodeng Xuexiao Huaxue Xue bao, 8, 314 (1987).

5. M. Umemoto and M. Kubota, Spectrochim. Acta, 42B, 491 (1987). 
6. G. Zaray, J. A. C. Broekaert and F. Leis, Spectrochim. Acta, 43B, 241 (1988).

7. M. Huang and X. E. Shen, Spectrochim. Acta, 44B, 957 (1989).

8. L. Halicz and I. B. Brenner, Spectrochim. Acta, 42B, 207 (1987).

9. H. Kawaguchi and G. -Y. Zhan, Bunseki Kagaku, 35, 972 (1986).

10. J. R. Dean and R. D. Snook, J. Anal. At. Spectrom., 1, 461 (1986).
11. M. Huang, Z. C. Jiang and Y. E. Zeng, Chem. J. Chinese Univ., 5, 288 (1989).

12. A. Taylor and P. Green, J. Anal. At. Spectrom., 3, 115 (1988).

13. R. D. Satzger, C. S. Clow, E. Bonnin and F. L. Fricke, J. Assoc. Off. Anal. Chem., 65, 987 (1982).

(Received June 4, 1990) (Accepted March 28, 1991) 